\title{
Mandible Protrusion and Decrease of TMJ Sounds: An Electrovibratographic Examination
}

\author{
Alicio Rosalino GARCIA \\ Sérgio FOLLI \\ Paulo Renato Junqueira ZUIM \\ Valdir de SOUSA \\ Department of Dental Materials and Prostheses, School of Dentistry of Araçatuba, \\ São Paulo State University, Araçatuba, SP, Brazil
}

\begin{abstract}
This study quantified by, electrovibratography, the amount of mandible protrusion required to decrease significantly temporomandibular joint (TMJ) vibratory energy as an aid in the diagnosis of the recapture of anteriorly displaced disk. Eighteen patients diagnosed as having anterior disk displacement with reduction and TMJ clicking were submitted to electrovibratographic examination at the first appointment and treated with a stabilizing appliance and anterior positioning appliance with 1 to $5 \mathrm{~mm}$ protrusion. Vibratory energy was checked in each of these positions. Baseline data were used as control. At the first appointment, the patients had vibrations with more elevated intensities at the middle and late phases of the mouth opening cycle. At only one clinical step, mandible protrusion was obtained with the anterior repositioning appliance, ranging from 1 to $5 \mathrm{~mm}$ protusion. At each new position, a new electrovibratographic exam was made. After the 5-mm mandibular projection, only 2 patients presented vibration, with means between 0.6 and $2.8 \mathrm{~Hz}$. Data were analyzed statistically by ANOVA and Tukey's test $(\alpha=0.05)$. The outcomes of this study indicate that $3 \mathrm{~mm}$ is the minimum amount of mandible protrusion to significantly decrease the TMJ vibratory energy and to recapture the displaced articular disk.
\end{abstract}

Key Words: temporomandibular joint, temporomandibular joint disorders, electrovibratography, dental occlusion.

\section{INTRODUCTION}

Anterior disk displacement with reduction is an internal temporomandibular joint (TMJ) disorder in which one of the most important characteristics is reciprocal clicking. Occlusal derangements, deep bite with insufficient horizontal overlap (1), interceptive occlusal contacts in the anterior teeth (2) and inadequate muscular activity of lateral pterygoid muscle (3) seem to be important in the development of this condition. Reflex activities are released, projecting the jaw backwards, producing morphologic alteration in the posterior border of the disk and elongating the ligaments that connect the disk to the condyle (4).

These alterations make the disk unstable on the condyle and, hence, it can move forwards. During mouth opening, the condyle moves forwards and passes over the posterior border of the disk until reaching its central portion. In the late phase of mouth closing, the disk is displaced again, producing a low-intensity sound attributed to condyle sliding on the retrodiscal area (5).

Clicking and crepitation should be considered as signs of morphological alterations, being indicative of anterior disk displacement with reduction (5) and arthrosis, respectively. Electrovibratographic records and macroscopic examinations of articulations of corpses showed that $20 \%$ of the TMJs with clicking had the disk displaced anteriorly and $22 \%$ of the TMJs with crepitation had arthrosis or disk perforation (6). Later recapture of the disk causes clicking at the end of mouth opening and indicates that the bilaminar zone is more affected (7). The microscopic aspects of disk surface can also be altered (8).

Several methods have been used to treat anterior

Correspondence: Prof. Dr. Alicio Rosalino Garcia, Departamento de Materiais Dentários e Próteses, Faculdade de Odontologia de Araçatuba, Universidade Estadual Paulista, UNESP, Rua José Bonifácio, 1193, Vila Mendonça, 16015- 050 Araçatuba, SP, Brasil. Tel/Fax: +55-18-2626 3245. e-mail: argarcia@ foa.unesp.br 
disk displacement. It has been verified that $62 \%$ of the patients treated with an anterior repositioning appliance presented recurrent articular sounds (9). It suggests that the TMJ structures have the capacity to adapt to different conditions and that persistence of articular sounds indicates that the disk ligaments do not shorten during the adaptation process. This demonstrates that most patients with articular sounds need complimentary physical therapy in order to strengthen the elevator muscles of the mandible (10).

For some authors, the treatment with anterior repositioning appliances in more severe situations of internal disorders involving disk displacement associated with osseous alterations is not very successful. Pain is significantly reduced after 1 week of appliance use (11) and occlusal splints can reduce both pain levels and joint clicking in patients with anterior disk displacement with reduction (12). However, stabilizing splints showed no efectiveness for TMJ clicking (13). Other authors have stated that, depending on use duration, anterior repositioning appliances can produce posterior open bite (14). On the other hand, others believe in the success of the therapy with these appliances (15).

TMJ surgery plays a small role in the management of patients with temporomandibular disorders (TMD). However, every surgical procedure should meet strict criteria of eligibility and scientifically proven criteria are still lacking (16).

In case of clicking recurrence after removal of the appliance used in the treatment of disk displacement, the patient should be submitted to occlusal correction by orthodontics or prosthodontics (17). Occlusal contacts usually conceal TMJ vibrations, decreasing the accuracy of palpation for a clinical diagnosis and making it difficult in some situations (18). In these cases, electrovibratography (EVG) can accurately identify the moment that vibrations occur and determine their characteristics (19). Patients with anterior disk displacement with reduction usually present greater TMJ vibrations at middle and late phases of mouth opening and at the late phase of mouth closing cycle (20).

The most accepted treatment for anterior disk displacement with reduction is the anterior repositioning of the mandible $(9,17)$ either followed or not by orthodontic or prosthetic rehabilitation. However, as far as it could be ascertained, the amount (in mm) of mandible protrusion has not yet been determined. It has been done either at random or based on information given by the patient and joint palpation/auscultation. This study quantified, by electrovibratography, the amount of mandible protrusion required to decrease significantly TMJ vibratory energy as an aid in the diagnosis of disk recapture in patients with anterior disk displacement.

\section{MATERIAL AND METHODS}

Eighteen patients ( 1 male and 17 females; age range 11-37 years old; mean age $=22.4$ years old) with anterior disk displacement with reduction were selected by means of clinical and radiographic examinations. As inclusion criteria, all patients should have clicking in both TMJs upon mouth opening and/or closing. Patients with muscular pathologies that can cause joint noises and crepitus, such as lateral pterygoid muscle spasm, and those diagnosed as having arthritis or articular degenerative disease were excluded from the study.

The participants used an anterior repositioning appliance during 4 months. However, this study evaluated only the amount of protrusion necessary to eliminate or reduce significantly TMJ sounds at the moment of appliance installation with 1.0 to $5.0 \mathrm{~mm}$ protrusion.

Patients had TMJ vibrations evaluated by electrovibratography (first appointment) using the BioJVA system (BioResearch Associates Inc., Milwaukee, WI, USA) connected to an IBM-compatible computer with SonoPak/I software (BioResearch) installed. This system has sensors (piezoelectric accelerometers) that were attached to the right and left joints and includes an amplifier to transfer and record the collected data.

After positioning the sensors, the patients were asked to open and close the mouth accompanying an arrow motion on the monitor screen. All patients were allowed 1 min of training to synchronize the movement with arrow motion. After confirming synchronism, the records were accepted, saved in a floppy disk and the patients with anterior disk displacement with reduction were submitted to the treatment. Irreversible hydrocolloid impressions (Jeltrate; Dentsply Ind. e Com. Ltda., Petrópolis, RJ, Brazil) were made of maxillary and mandibular arches and casts were obtained by pouring type IV stone (Durone; Dentsply Ind. e Com. Ltda.).

After mounting the maxillary cast in an arcon type articulator (Gnatus 8600; Gnatus, Ribeirão Preto, SP, Brazil), with facial bow, an autopolymerizing acrylic resin (Duralay; Reliance, Dental Mfg. Co Worth, IL, USA) Lucia's jig was made lo locate the centric relation 
position of the mandible to maxilla. Interocclusal records were made in wax, relined with zinc-oxide and eugenol paste (Lysanda, São Paulo, SP, Brazil) and the mandibular cast was mounted on the articulator. A vacuum stabilizing appliance was prepared in the maxillary cast and the occlusal surface was relined with colorless autopolymerizing acrylic resin (Jet; Artigos Odontológicos Clássico Ltda, São Paulo, SP, Brazil). The device was fitted and adjusted in the patient's dental arch. Immediately after installation, a new electrovibratographic examination was done to measure TMJ vibrations with the stabilizing appliance.

After confirming the presence of articular vibrations, the appliance was put back in its respective cast in order to perform mandible protrusion in the articulator. The first mandible projection was of $1.0 \mathrm{~mm}$ by placing strips of radiographic film (Eastman Kodak Company, Rochester, NY, USA) of known thickness between the condylar sphere and posterior wall of the articulator mechanism. An anterior guidance was made in the appliance with the same colorless autopolymerizing acrylic resin, in such a way that the mandibular incisors could guide mouth closing with the mandible $1 \mathrm{~mm}$ ahead. Thereafter, the device was called "anterior repositioning appliance". The anterior $1 \mathrm{~mm}$ projection repositioning appliance was positioned in the mouth and a new electrovibratographic record was obtained. Protrusions of the mandible with 2, 3, 4 and $5 \mathrm{~mm}$ were performed in the articulator in the same session. For each new mandible protrusion, the anterior positioning appliance was relined and a new electrovibratographic record was obtained. After returning to the smallest mandible projection sufficient to eliminate or reduce TMJ vibrations, confirmed by electrovibratography, the appliance's occlusal surface was relined, polished and the mandible was positioned forwards. Four measurements were made for each electrovibratographic examination and 3 readings were made for each analysis. Means were tabulated for statistical analysis by ANOVA and Tukey's test at 5\% significance level.

\section{RESULTS}

Articular clicking was the main complaint, being reported by $100 \%$ of the patients, followed by TMJ pain $(50 \%)$, headache $(27.7 \%)$, locking $(22.2 \%)$ and earache $(11.1 \%)$. Other less common complaints were neck pain, dizziness, buzzing and limitation of functon.

The articular sounds had a gradual decrease of vibrations as the mandible was advanced by the interocclusal device. In most phases, the articular vibrations decreased after installation of the stabilizing appliance compared to the vibrations recorded at baseline, though without statistically significant differences (Table 1). The articular vibrations were more frequent and intense at the end of mouth opening (Table 1).

Table 1. Means of vibratory energy (in $\mathrm{Hz}$ ) recorded at the beginning, middle and end of the mouth opening and closing cycles in the left (L) and right (R) temporomandibular joints of the 18 patients with displacement of the disk with reduction at the first clinical appointment (FCA), after use of the stabilizing appliance (SA) and with 1, 2, 3, 4 and $5 \mathrm{~mm}$ of mandible protrusion.

\begin{tabular}{|c|c|c|c|c|c|c|c|c|c|c|c|c|}
\hline & \multicolumn{6}{|c|}{ Opening } & \multicolumn{6}{|c|}{ Closing } \\
\hline & \multicolumn{2}{|c|}{ Beginning } & \multicolumn{2}{|c|}{ Middle } & \multicolumn{2}{|c|}{ End } & \multicolumn{2}{|c|}{ Beginning } & \multicolumn{2}{|c|}{ Middle } & \multicolumn{2}{|c|}{ End } \\
\hline & $\mathrm{L}$ & $\mathrm{R}$ & $\mathrm{L}$ & $\mathrm{R}$ & $\mathrm{L}$ & $\mathrm{R}$ & $\mathrm{L}$ & $\mathrm{R}$ & $\mathrm{L}$ & $\mathrm{R}$ & $\mathrm{L}$ & $\mathrm{R}$ \\
\hline FCA & $0 \mathrm{a}$ & $0 \mathrm{a}$ & $52.1 \mathrm{a}$ & $71.3 \mathrm{a}$ & $93.2 \mathrm{a}$ & $137.4 \mathrm{a}$ & $11.8 \mathrm{a}$ & $14.5 \mathrm{a}$ & $7.5 \mathrm{a}$ & $4.7 \mathrm{a}$ & $34.9 \mathrm{a}$ & $35.2 \mathrm{a}$ \\
\hline $\mathrm{SA}$ & $1.4 \mathrm{a}$ & $1.4 \mathrm{a}$ & $32.2 \mathrm{a}, \mathrm{c}$ & $37.3 \mathrm{a}, \mathrm{c}$ & $58.3 \mathrm{a}, \mathrm{c}$ & $64.1 \mathrm{a}, \mathrm{c}$ & 4.1a & $1.2 \mathrm{a}$ & $8.5 \mathrm{a}$ & $7.3 \mathrm{a}$ & $20.9 \mathrm{a}$ & $33.5 \mathrm{a}$ \\
\hline $1 \mathrm{~mm}$ & $4.2 \mathrm{a}$ & $2.4 \mathrm{a}$ & $26.2 \mathrm{a}, \mathrm{c}$ & $24.6 \mathrm{a}, \mathrm{c}$ & $28.8 \mathrm{a}, \mathrm{c}$ & $38.8 \mathrm{a}, \mathrm{c}$ & $33.2 \mathrm{a}$ & $40.5 \mathrm{a}$ & $5.2 \mathrm{a}$ & $5.6 \mathrm{a}$ & $23.0 \mathrm{a}, \mathrm{c}$ & $22.1 \mathrm{a}, \mathrm{c}$ \\
\hline $2 \mathrm{~mm}$ & $0 \mathrm{a}$ & $0 \mathrm{a}$ & $7.4 a, c$ & $8.8 \mathrm{~b}, \mathrm{c}$ & $22.0 \mathrm{~b}, \mathrm{c}$ & $30.8 \mathrm{a}, \mathrm{c}$ & $15.3 \mathrm{a}$ & $8.6 \mathrm{a}$ & $1.1 \mathrm{a}$ & $1.2 \mathrm{a}$ & $11.4 \mathrm{a}, \mathrm{c}$ & $16.7 \mathrm{a}, \mathrm{c}$ \\
\hline $3 \mathrm{~mm}$ & Oa & $0 \mathrm{a}$ & $3.8 \mathrm{~b}, \mathrm{c}$ & $4.1 b, c$ & $5.6 \mathrm{~b}, \mathrm{c}$ & $8.2 \mathrm{~b}, \mathrm{c}$ & $1.0 \mathrm{a}$ & $0.6 \mathrm{a}$ & $0 \mathrm{a}$ & $0 \mathrm{a}$ & $2.1 b, c$ & $3.6 \mathrm{~b}, \mathrm{c}$ \\
\hline $4 \mathrm{~mm}$ & $0 \mathrm{a}$ & Oa & $3.6 b, c$ & $4.2 \mathrm{~b}, \mathrm{c}$ & $4.1 \mathrm{~b}, \mathrm{c}$ & $4.3 \mathrm{~b}, \mathrm{c}$ & $0 \mathrm{a}$ & $0 \mathrm{a}$ & 0a & Oa & $2.3 \mathrm{~b}, \mathrm{c}$ & $3.3 \mathrm{~b}, \mathrm{c}$ \\
\hline $5 \mathrm{~mm}$ & $0 \mathrm{a}$ & $0 \mathrm{a}$ & $0.6 b, c$ & $1.0 \mathrm{~b}, \mathrm{c}$ & $2.5 \mathrm{~b}, \mathrm{c}$ & $2.8 \mathrm{~b}, \mathrm{c}$ & $1.1 \mathrm{a}$ & $1.1 \mathrm{a}$ & $0 \mathrm{a}$ & $0 \mathrm{a}$ & $0 b, c$ & $0 b, c$ \\
\hline
\end{tabular}


After installing the repositioning appliance with 1 $\mathrm{mm}$ mandible protrusion, the means of articular vibrations were still lower in the middle point and at the end of mouth closing (Table 1). Even though, these results have no statistically significant difference in relation to the baseline data (Table 1). With use of the appliance, a change in the position of vibration occurred in relation to the mandibular movement cycle. None of the 18 patients presented vibrations in the initial opening movement at the fisrt appointment, but after installation of the anterior positioning appliance, 11 patients presented vibrations.

The reduction of the articular vibrations after installation of the anterior positioning with $2 \mathrm{~mm}$ of protrusion was more evident and statistically significant on one of the patient's sides, in the middle point as well as at the end of the opening cycle (Table 1). With $2 \mathrm{~mm}$ of mandible projection, only 3 patients $(16.6 \%)$ presented no articular vibrations, which were present in the other 15 patients $(83.4 \%)$.

When the anterior positioning appliance moved the mandible $3 \mathrm{~mm}$ forwards, 9 patients $(50 \%)$ presented no vibration in both TMJs. The decrease of articular vibrations on both patients' sides was statistically significant when mandible was protruded $3 \mathrm{~mm}$ (Table 1). The remaining vibrations occurred mainly in the middle point, at the end of mouth opening and at the beginning and at the end of mouth closing. Intensities below $20 \mathrm{~Hz}$ were recorded, which are much smaller than those recorded at baseline.

With $4 \mathrm{~mm}$ mandible projection,14 patients (77.8\%) presented no vibration in both TMJs in the opening and closing cycles. Only 4 patients $(22.2 \%)$ presented some vibration in the middle point or at the end of mouth opening and closing (Table 1). The statistical analysis showed that TMJ vibrations with the mandible protruded $4 \mathrm{~mm}$ were significantly different from those recorded at first clinical appointment (baseline data), but were statistically similar to those obtained with $3 \mathrm{~mm}$ projection (Table 1).

The increase of mandible projection up to $5 \mathrm{~mm}$ eliminated significantly the vibrations in the middle point and at the end of mouth opening and closing in 16 patients $(88.9 \%)$ (Table 1). However, in some patients in which articular vibrations had disappeared with $3 \mathrm{~mm}$ mandible projection, there was a recurrence or even increased of vibrations after projecting the mandible 5 $\mathrm{mm}$ ahead.

\section{DISCUSSION}

The posterior position of the condyle, in addition to morphological alterations in the posterior border of the disk (6), can produce stretching of the intracapsular ligaments that slowly elongate (4), contributing to displace the disk forwards. The more stretched the ligaments, the more medially and anteriorly the disk will be positioned and the later it will be recaptured during the mouth opening cycle (6). At the moment that the disk is replaced on the condyle, locking disappears and sound energy is released in the form of clicking high vibratory intensity (268 to $594.7 \mathrm{~Hz}$ ) (5).

With the installation of the anterior repositioning appliance, the means of vibratory intensities decreased and vibrations became registered in a more premature position (beginning of opening). Recapturing the disk at the beginning of opening can be related to the amount of separation between the dental arches produced by the interocclusal device, which could have caused a forward rotation of the condyle. In association with the immediate effect of muscular activity reduction for decrease of the proprioceptive impulses produced by the device, this seems to have reduced the pressure among the TMJ structures. In addition to separating the condyle of the disk and the temporal bone, this smaller intra-articular pressure must have allowed disk rotation backwards, favoring its recapture partially or permitting a softer movement during its replacement.

After the installation of the anterior positioning appliance with $1 \mathrm{~mm}$ of mandible projection, a slightly larger reduction was observed in the means of vibratory intensities, in the middle point and at the end of mouth opening and closing. This decrease may have been influenced by disk recapture in some patients or partial replacement associated with the reduction of the pressure in the intra-articular structures in other situations. In some patients, TMJ vibrations after installation of the anterior repositioning appliance with $1 \mathrm{~mm}$ of mandible projection was of low intensity. This condition suggests that the mandible projection produces a partial disk reduction or recapture that takes the condyle positioning on areas without structural arrangements produced by the morphological alterations caused by disk displacement, as verified in anatomic studies (4) and magnetic resonance (7). Additionally, disk surfaces, especially with more internal disorders, can exhibit fissures, fibrillations, lacerations and signs of degeneration in the main 
extra-cellular matrix, which include increase or regional reduction of the number of cells, chondromalacia, reduction of the elastic fibers, cystic lesions and dystrophic mineralization (8). In any of these situations, during opening and closing, the passage of the condyle over those irregularities can produce low-intensityvibrations, which probably needs some time to disappear. As the mandible projection was increased to $2,3,4$ and $5 \mathrm{~mm}$, the TMJs became silent, suggesting that recapture of the disk was complete and allowed the condyle to adapt on the concavity and the flat portion of the disk. This, in most situations, does not have significant morphological alterations.

The statistical analysis indicated that the anterior replacement of $3 \mathrm{~mm}$ was the smallest mandible projection capable to produce the best result in disk recapture. In patients who presented vibrations with the anterior repositioning appliance projecting the mandible $2 \mathrm{~mm}$ forwards, the TMJs became silent after projecting their mandible $3 \mathrm{~mm}$. In this situation, the condyle was positioned in the concavity and the flat portion of the disk, which allows a movement without vibration of the articular structures. On the other hand, patients who presented low vibratory intensity with $2 \mathrm{~mm}$ mandible projection, which was not eliminated with the anterior position of $3 \mathrm{~mm}$, had constant vibrations relating to both the movement cycle and the vibratory intensity. This indicates that the condyle was on areas of morphological alterations in the disk (7). In some patients, these structural modifications are accentuated and responsible for the movement of the disk during the condylar movement. In order to decrease or eliminate these vibrations, exercises have been recommended for muscular invigoration (10). The compression applied by the condyle during exercise seems to remodel the disk and turn the articular surfaces more regular and smooth.

Projection above $3 \mathrm{~mm}$ did not always produce a favorable result. One of the patients who had silent TMJs with $3 \mathrm{~mm}$ protrusion, started to have lowintensity vibrations with use of the anterior repositioning appliance of $4 \mathrm{~mm}$. These vibrations were detected by electrovibratography, but were imperceptible to the patient's listening capacity. This suggests that this patient presents alterations in the structure of the articular disk $(4,7,8)$, located in several areas. Small variations in the position of the condyle can place it on unstable areas with production of articular vibrations.

Mandible projections of 4 and $5 \mathrm{~mm}$ tend to produce discomfort to the patient and, sometimes, auditory symptoms, such as subjective deafness or pain in the posterior area of the head by stretching the posterior bunch of the temporal muscle. In addition, the benefit related to the reduction of vibrations was statistically similar to that of $3 \mathrm{~mm}$ protrusion, which indicates that the results achieved with disk replacement can be analogous.

Studies have shown that, after mandible projection of $3 \mathrm{~mm}$, some patients still display articular vibrations. They need physical therapy to remodel the structure of the articular disk and strengthen the elevator muscles of mandible (10) and present anatomic alterations verified by direct examination (4) or magnetic resonance imaging (7). After some months of exercises, the vibrations tend to disappear. However, it is uncertain whether they will disappear permanently or will return after removal of the anterior repositioning appliance. These observations will be the subject of future discussions and for that these answers will be obtained from observations taken from the time these patients were first interviewed. When recurrence of the vibrations occurs after removal of the appliance, dental occlusion should be revised to increase the horizontal overlap and allow the mandible to be positioned further forwards in such a way to maintain the orthopedic balance between the articular structures and mandible.

The findings of this study demonstrated that the amount of mandible projection required to significantly reduce TMJ sounds in patients diagnosed with anterior disk displacement with reduction is $3 \mathrm{~mm}$, starting from the centric relation position.

\section{RESUMO}

Este trabalho teve por finalidade quantificar a protrusão mandibular necessária para diminuir significativamente a energia vibratória da articulação temporomandibular (ATM), verificada por meio da eletrovibratografia, como um meio auxiliar de diagnóstico da recaptura do disco articular deslocado anteriormente. Dezoito pacientes com diagnóstico de deslocamento anterior do disco com redução e estalos na ATM foram submetidos ao exame eletrovibratográfico na consulta inicial e tratados com placa oclusal estabilizadora e placa reposicionadora anterior com protrusão variando de 1 a $5 \mathrm{~mm}$, checando-se a energia vibratória em cada uma destas posições. Os dados obtidos na consulta inicial foram usados como grupo controle. Na consulta inicial, os pacientes apresentaram vibrações com intensidades mais elevadas no meio e final da abertura bucal. Em uma única sessão, a protrusão era realizada a partir de $1 \mathrm{~mm}$ por meio de placa reposicionadora anterior e realizado novo exame de imediato, 
até atingir $5 \mathrm{~mm}$. Após a mandíbula ser protruída $5 \mathrm{~mm}$, apenas 2 pacientes apresentavam alguma vibração, com uma média de 0,6 a 2,8 Hz. A análise estatística foi realizada por análise de variância e teste de Tukey $(\alpha=0,05)$. Os resultados indicaram que $3 \mathrm{~mm}$ seria a protrusão mínima necessária para reduzir significantemente a energia vibratória e recapturar o disco articular.

\section{ACKNOWLEDGEMENTS}

The authors acknowledge FAPESP for the financial support (process number 2001/04106-0).

\section{REFERENCES}

1. Berry DC, Watkinson AC. Mandibular dysfunction and incisor relationship: a theoretical explanation for the clicking joint. Brit Dent J 1978;144:74-77.

2. Dolwick MF, Katzberg RW, Helms CA. Internal derangements of the temporomandibular joint: fact or fiction? J Prosthet Dent 1983;49:415-418.

3. Bakke M, Moller E, Werdelin LM, Dalager T, Kitai N, Kreiborg S. Treatment of severe temporomandibular joint clicking with botulinum toxin in the lateral pterygoid muscle in two cases of anterior disc displacement. Oral Surg Oral Med Oral Pathol Oral Radiol Endod 2005;100:693-700.

4. Westesson PL, Bronstein SL, Liedberg J. Internal derangement of the temporomandibular joint: morphologic description with correlation to joint function. Oral Surg Oral Med Oral Pathol 1985;59:323-331.

5. Muhul ZF, Sadowsky C, Sakols EI. Timing of temporomandibular joint sounds in orthodontic patients. J Dent Res 1987;66:1389-1392.

6. Rohlin M, Westesson PL, Eriksson L. The correlation of temporomandibular joint sounds with joint morphology in fifty-five autopsy specimens. J Oral Maxillofac Surg 1985;43:194-200.

7. Taskay-Yilmaz N, Ogutcen-Toller M. Magnetic resonance imaging evaluation of temporomandibular joint disc deformities in relation to type of disk displacement. J Oral Maxillofac Surg 2001;59:860-865.

8. McNeill CH. Science and practice of occlusion. Chicago: Quintessence; 2000.

9. Okeson JP. Long-term treatment of disk-interference disor- ders of the temporomandibular joint with anterior repositioning occlusal splints. J Prosthet Dent 1988;60:611-616.

10. Nicolakis P, Edogmus B, Djaber-Ansari A, Piehslinger E, Fialkmoser V. Exercise therapy for craniomandibular disorders. Arch Phys Med Rehabil 2000;81:1137-1142.

11. Eberhard D, Bantleon HP, Steger W. The efficacy of anterior repositioning splint therapy studied by magnetic resonance imaging. Eur J Orthod 2002;24:343-352.

12. Fayed MM, El-Mangoury NH, El-Bokle DN, Belal AI. Occlusal splint therapy and magnetic resonance imaging. World J Orthod 2004;5:133-140.

13. Wassell RW, Adams N, Kelly PJ. The treatment of temporomandibular disorders with stabilizing splints in general denta practice: one-year follow-up. J Am Dent Assoc 2006;137:1089-1098.

14. Kai S, Kai H, Tabata O, Tashiro H. The significance of posterior open bite after anterior repositioning splint therapy for anterior displaced disk of the temporomandibular joint. Cranio 1993;11:146-152.

15. Kurita H, Ohtsuka A, Kurashima K, Kopp SL. A study of factors for successful splint capture of anteriorly displaced temporomandibular joint disc with disc repositioning appliance. J Oral Rehabil 2001;28:651-657.

16. Dolwick MF. Temporomandibular joint surgery for internal derangement. Dent Clin North Am 2007;51:195-208.

17. Tallents RH, Katzberg RW, Macher DJ, Roberts CA. Use of protrusive splint therapy in anterior disk displacement of the temporomandibular joint: a 1 to 3 year follow-up. J Prosthet Dent 1990;63:336-341.

18. Paesani D, Westesson PL, Hatala MP, Tallents RH, Brooks SL. Accuracy of clinical diagnosis for TMJ internal derangement and arthrosis. Oral Surg. Oral Med Oral Pathol 1992;73:360-363.

19. Ishigaki S, Bessete RW, Maruyama T. Vibration analysis of the temporomandibular joints with degenerative joint disease. J Cranio 1993;11:276-283.

20. Oster C, Katzberg RW, Tallents RH, Morris TW, Holomew BJ, Miller TL, et al.. Characterization of temporomandibular joint sounds: a preliminary investigation with arthrographic. Oral Surg Oral Med Oral Pathol 1984;58:10-16.

Accepted May 3, 2007 